\section{Yrigoyen y la Argentina durante la Gran Guerra según los agregados militares franceses}

Hernán Otero

Hernán Otero es Profesor de la Universidad Nacional del Centro de la Provincia de Buenos Aires, e Investigador del CONICET con sede en el Instituto de Estudios Históricos y Sociales (IEHS) de esa universidad. Es además miembro asociado del Centre d'Études NordAméricaines (CENA-MASCIPO) de la de l'École des Hautes Etudes en Sciences Sociales, Paris.

Dirección institucional: Gral. Pinto 348, (7000) Tandil, Provincia de Buenos Aires, Argentina. Telefax: (2293) 44-5683

e-mail: hernan.otero@speedy.com.ar

\section{Resumen}

El artículo analiza la visión que tenían los agregados militares franceses de la sociedad argentina y del gobierno de Yrigoyen. Basado en información inédita de la Serie N del Service Historique de l'Armée de Terre, se describen las amplias funciones de los agregados militares durante el conflicto, focalizando la atención en la percepción de estos funcionarios en temas tales como la guerra económica, la división de la sociedad en aliadófilos y germanófilos, el papel del ejército y de la Iglesia, las orientaciones de la prensa nacional y étnica y, sobre todo, la neutralidad del Presidente Hipólito Yrigoyen. El texto propone asimismo un análisis de las ventajas y límites de los informes elaborados por los agregados militares y concluye con hipótesis exploratorias sobre la importancia de sus diagnósticos para las ulteriores acciones diplomáticas francesas en el país y sobre las diferencias de percepción entre los agregados militares franceses y diplomáticos de otros países en guerra, en particular Gran Bretaña.

\section{Summary}

The article analyzes the French military attaches' view regarding Argentinian society and Yrigoyen's rule. Based on the non-published data from the $\mathrm{N}$-series of the Service Historique de l'Armée de Terre, the text describes the varied roles the military attaches played during the conflict, focusing on these officials' standpoints about central topics such as economic war, social division between pro-allies and sympathizers for Germany, the roles of the army and the Church, political orientations of the national and ethnic press and, above all, president Hipolito Yrigoyen's neutrality. On top of it, the article explores the advantages and limits of the reports presented by the military attaches, and finally concludes with exploratory hypotheses about the importance of their evaluations for the future French diplomatic measures in Argentina and the differences in perception we can see between these French military attaches and diplomats from other countries involved also in the international conflagration, in particular Great Britain. 